\title{
Building for an exit (or not)
}

\section{Thomas G Gunning}

\section{A young biotech firm can grow in several ways. The key to success is preparing for them all.}

\begin{abstract}
$A s$ an entrepreneur at a biotech startup, Ayou have a lot on your mind. You must simultaneously prepare for venture financing, attracting partnerships, going public, a trade sale and the successful launch of a lead product. Being ready for all these options is necessary because it allows access to the 'right' transaction and negotiating leverage at each step of development, but many biotech firms actually execute on most or even all of the options as they grow. Without developing all options at all times, you may lack 'walk-away power' and risk being squeezed into a bad transaction by a venture investor, a big pharma partner or a buyer when your company is short on cash.
\end{abstract}

\section{Prepare, prepare, prepare}

Of course, lots of companies do prepare correctly. Waltham, Massachusetts-based Adnexus Therapeutics is a fine example. Adnexus was incorporated in 2002 and acquired proprietary rights to technology and its lead oncology product candidate in 2003. By February 2007, it had signed an alliance with Bristol-Meyers Squibb (BMS), of New York, yielding an initial \$20 million payment with total milestones up to $\$ 211.5$ million. In August that year, it ended its venture capital cycle by bringing in $\$ 15$ million, raising its total to $\$ 70$ million, and it filed an initial public offering (IPO) registration that same month. It never went public, but was bought by BMS for $\$ 415$ million just a month later. In other words, between February 2007 and September 2007, Adnexus signed a major alliance, closed a venture round, filed to go public and sold the company, yielding fantastic returns to founders and investors. Not too shabby.

On the other hand, there are plenty of examples of fiascos to learn from. Typically, failure can be brought on by disorganization (Box 1)

Thomas G. Gunning is Vice President and General Counsel at EMD Serono, One Technology Place, Rockland, Massachusetts 02370, USA. e-mail: thomas.gunning@emdserono.com or by missed transaction timing (Box 2), among other pitfalls. Life science ventures are different from those in other industries. In drug development, the path is long, astronomically expensive and very risky. A visionary bioentrepreneur like yourself cannot build a company with credit card debt, as some successful internet companies did in the 1990s. Instead, you must be ready to make deals with venture capitalists, big pharma, the equity markets and a buyer. In fact, a 'traditional' model for developing a biopharmaceutical company is first to raise money from a venture firm, which brands the company as a 'good investment'; then sign a co-development/marketing deal with big pharma, which brands the lead product as a 'good product'; then score an IPO, which brands your clinical prospects as 'promising'; and finally launch a product, with the prospect of a company sale anywhere along the line. Many firms have developed in just this way (Table 1).

\section{Building for all transaction options}

There are several steps you can take to ensure that appropriate transaction options are avail- able at critical junctures. In particular, as an executive, you should focus on a few core elements.

- Your product must be targeted to meet an unmet medical need.

- You must have 'freedom to operate' and exclusivity in the field.

- You should have the right management team and advisors.

- You should avoid contingent liabilities.

These elements are important for all transactions along the development line. As a founding scientist and entrepreneur, you may not be focused on an exit or a 'liquidity event' like a company sale, but the venture investors on whom you will necessarily rely are singularly focused on it. The good news is that the factors that make a company attractive for sale are the same factors that make it attractive for successive 'up' rounds of venture investment, big pharma partnerships or an IPO. So to maximize transaction options and avoid being squeezed, as I've explained in Box $\mathbf{1}$ and Box 2, you must be focused on these building blocks from the outset. Great science is not enough to ensure entrepreneurial success.

\section{Box 1 Disorganization breeds failure}

Consider this example: a bright scientist becomes the founder of a startup. The startup is funded by angel investors and friends and family to advance a product. The founder begins looking for professional venture money when the company has six months' cash reserve, expecting to close in three months at a high valuation. The key elements of the financing effort are a business plan and the founder's excitement with the product. But the founder has given little thought to proper corporate organization, to documenting employee equity grants, to the track record of his or her management team or the company's ability to operate freely in the space, given other patented technologies and products. In other words, the entrepreneur has not planned well for any type of transaction except one based on the trust of friends and family investors. The result-the company likely finds no venture interest and no interest in any other transaction type, either. The company spends a year hiring the right management and advisors, cleaning up sloppy corporate organization and clarifying intellectual property rights. Eighteen months after the start of the process, the company closes a first venture round at a valuation lower than hoped. During that 18-month period of housekeeping, competing products advance, thereby jeopardizing the startup's ultimate chances of success. 


\section{Box 2 Crisis of the closed IPO window}

In a second classic situation, the entrepreneur successfully builds the core business and raises, then spends, tens of millions of venture capital dollars. The young company has a management team, 50 employees, a few promising preclinical targets, one product in a phase 2 study and a second product in the first of two planned phase 3 registration studies. Patents are filed, and the lead product is targeted to meet an unmet medical need with a market size of $\$ 2$ billion. The management team and scientists are committed to the company for the long term and are loaded up with low-priced stock options, expecting to become millionaires in an IPO arranged by their lead venture investor. The company focuses its attention on the phase 3 study hoping to have interim results to support the IPO. It has six months' cash reserve when the IPO window shuts due to a significant market correction.

Discussions then commence with big pharma to co-promote the company's phase 3 candidate, with the expectation of a significant up-front payment and development milestones to sustain the company until the IPO window opens. Given the confidence in the value of its pipeline and lead product in particular, the company does not seek bridge financing, believing that it can always go back to its venture investors if needed.

Nine months later and very low on cash to meet payroll, the company realizes its prospective big pharma partner is playing the time game and dragging out negotiations knowing the company has not arranged other alternatives. With the IPO window still closed, big pharma changes the discussion from a sustaining partnership to an acquisition. Big pharma comes with an acquisition price at the low end of reasonable and threatens to walk if the company runs an auction process to generate competitive bids. The proposed acquisition price yields a respectable return to the venture investors on their preferred stock, but yields little return to management on their equity. The venture investors decline the company's request for a bridge financing, instead opting for an immediate exit with the respectable return. Big pharma completes the acquisition, the founding scientists get a modest pay day on their equity and become employees earning a paycheck with little equity stake in their former company or product targets going forward.

\section{Building block 1: product meets unmet medical need}

The United States is the biggest market for biopharmaceutical products in the world, and all political forces work to limit payments by government and private insurers to those products that set the standard of care in a defined patient population and have patent or orphan drug exclusivity. (There is also room for high-quality, low-cost generics.) The political forces include legislative proposals to permit 'generic' follow-on biologics; patent reform, which would ease challenges to innovative products; measures to permit government negotiation of product prices; and comparative effectiveness studies sponsored by the government to ensure only the 'best' product is fully reimbursed. Europe has already gone in this direction, with government agencies making treatment recommendations and coverage decisions, favoring the most effective and lowest cost products. So the days of 'me-too' products are limited.

In this environment, you must rigorously screen product candidates. Will your product candidate set the standard of care? Can exclusivity be obtained through patents, orphan drug status or both (Table 2 )?

Also, what types of clinical studies, including head-to-head studies to show superior efficacy, are needed to have a data package necessary to convince public and private payor systems with strained budgets to pay for the product? All of these questions must be answered to select for development a product that is most likely to be a commercial success.

\section{Building block 2: 'freedom to operate' and exclusivity}

Without a product that meets an unmet medical need and has 'freedom to operate' in the market and patent or orphan drug exclusivity, the expected sales and market value of a drug candidate is limited, and likely to be much more limited in the future. It is important that you evaluate and understand both freedom to operate, which is the ability to promote a product without infringing another company's patents, and potential exclusivity through patents or orphan drug designation. You also must establish the patent and orphan exclusivity of your product, which allows the company to block competitive products.

Freedom to operate involves an analysis of the patent and orphan drug designation of other products in a proposed indication.

Table 1 Development trajectories of three biopharmaceutical companies

\begin{tabular}{|c|c|c|c|c|c|c|}
\hline Company & Date founded & $\begin{array}{l}\text { Number of } \\
\text { VC rounds/total } \\
\text { raised (\$M) }\end{array}$ & $\begin{array}{l}\text { Partners } \\
\text { (location)/date }\end{array}$ & IPO date & $\begin{array}{l}\text { Sale price } \\
(\$ M) / \text { date/buyer }\end{array}$ & Transaction order \\
\hline Adnexus Therapeutics & 2002 & $2 / 70$ & BMS/2007 & $\begin{array}{l}\text { Filed } 2007 \\
\text { (aborted due to sale) }\end{array}$ & 415/2007/BMS & $\begin{array}{l}\text { Two venture rounds } \\
\text { Pharma partnership } \\
\text { Sale }\end{array}$ \\
\hline $\begin{array}{l}\text { Sirtris Pharmaceuticals } \\
\text { (Cambridge, } \\
\text { Massachusetts) }\end{array}$ & 2004 & $4 / 103$ & None & 2007 & $\begin{array}{l}\text { 720/2008/ } \\
\text { GlaxoSmithKline } \\
\text { (London) }\end{array}$ & $\begin{array}{l}\text { Two venture rounds } \\
\text { IPO } \\
\text { Sale }\end{array}$ \\
\hline
\end{tabular}

VC, venture capital; BMS, Bristol-Myers Squibb. 
For example, if you have identified a new product candidate for Pompe disease, it is important to understand the scope of existing third-party patents and any orphan designations in that field. If the field is well covered by existing patents or orphan designations on effective products or promising candidates, the value of a new product may be low unless it will dramatically change the standard of care.

Once the competitive landscape and freedom to operate is well understood, bioentrepreneurs need to acquire exclusivity for their products through patents, orphan drug exclusivity or both. The market potential of any new product is in large part defined both by a company's ability to market its product without interference from others (freedom to operate) and the availability of exclusivity platforms that allow it to prevent others from selling competing products (patents and orphan exclusivity).

\section{Building block 3: hiring the right management team, advisors}

Experience counts. Venture capitalists receive hundreds of business plans. They will surely not have a full appreciation for your technology and target product based on your business plan. However, they will get an immediate sense of your company from the track record of your management team. Management team and outside advisors should have experience in their fields and in preparing a company for venture financing, pharmaceutical partnership, IPO and sale. In other words, experienced management will ensure that the company has options that create walk-away power, leverage for negotiating good deals and the best opportunity to maximize outcomes and achieve its potential.

The right management team and advisors will also help the company avoid mistakes. In Box 1, our early-stage biopharmaceutical company was delayed in securing financing because of organizational mistakes. In later-stage companies, sloppy contracting can become a problem. For example, in a rush to complete a license agreement, startups sometimes agree to restrict their freedom to operate by contract. They might in-license a technology or even a product for development but restrict use in certain indications and fields. Worst still, they might agree not to compete in certain fields. Experienced management and advisors will ensure an early-stage company does not unwittingly make mistakes that will adversely affect future transactions and reduce options.

\section{Table 2 Comparison of patent protection, orphan drug exclusivity}

Composition patent

Orphan drug

Standard for obtaining Novelty; utility; nonobviousness

protection

Rare disease affecting fewer than 200,000 people in the United States. First orphan product approved for that disease.

Duration of exclusivity Twenty years from earliest priority date Seven years from approval plus potential patent term extension

Scope of protection Can prevent others from making, using, selling, offering to sell or importing product in any country in which patents are issued

No other product approval will be granted in United States without showing superior efficacy or safety.

\section{Building block 4: avoid contingent liabilities}

In any transaction, whether financing, sale or IPO, expect extensive due diligence on your company. This process is intended not only to confirm facts but also to uncover contingent liabilities. Large contingent liabilities make it more difficult and perhaps impossible to close transactions.

In the biopharmaceutical area, compliance concerns are now a serious contingent liability that cannot be overlooked by a company. Compliance concerns include the failure of a company to have a compliance program in place or to comply with all applicable laws. Of particular concern is any failure to comply with prohibitions under the Food, Drug and Cosmetic Act on preapproval or off-label product promotion or federal antikickback laws, which prohibit paying anything of value in exchange for the referral of business (including drugs) paid for under Medicaid or Medicare. Several pharmaceutical and biopharmaceutical companies have settled criminal and civil investigations by federal and state prosecutors and entered so-called corporate integrity agreements, that regulate their operations going forward, and the operations of any companies they acquire (Table 3 ).

If an acquired company is out of compliance (or subject to any other large contingent liability), then the buyer may inherit the large liability. For example, New York-based Pfizer paid \$430 million postacquisition for the preacquisition conduct of the Warner Lambert division, and Jazz Pharmaceuticals in Palo Alto, California, paid \$20 million for the preacquisition conduct of Orphan Medical. Because compliance concerns and other contingent liabilities may adversely affect sale prospects, they also are of great interest to venture capitalists, IPO underwriters and big pharma partners.

\section{Conclusions}

The development and launch of a biopharmaceutical product often takes more than ten years at a cost in excess of $\$ 1$ billion. A bioentrepreneur must be flexible and prepared to complete the right transactions at the right times to maximize success. What is 'right' will change with circumstances, so the only way to be prepared is to always be prepared for them all. Without having multiple options and thus, walk-away power, you might be squeezed and receive substantially less return on your innovations. On the other hand, if you develop all options, you will have leverage and the luxury of picking the and financial returns. transactions that realize maximum potential

Table 3 Notable corporate integrity agreement (CIA) settlements (2005 to present)

\begin{tabular}{lcc} 
Company (location) & Date of CIA & Settlement payment (\$M) \\
\hline Merck (Whitehouse Station, New Jersey) & $2 / 5 / 08$ & 650 \\
\hline Bristol-Myers Squibb (New York) & $9 / 26 / 07$ & 515 \\
\hline Sanofi-Aventis (Paris) & $8 / 30 / 07$ & 190 \\
\hline Purdue Pharma (Stamford, Connecticut) & $5 / 8 / 07$ & 634.5 \\
\hline Medicis (Scottsdale, Arizona) & $4 / 25 / 07$ & 9.8 \\
\hline InterMune (Brisbane, California) & $10 / 25 / 06$ & 36.9 \\
\hline Eli Lilly (Indianapolis) & $12 / 21 / 05$ & 36 \\
\hline King Pharmaceuticals (Bristol, Tennessee) & $10 / 31 / 05$ & 124 \\
Serono Laboratories (Rockland, Massachusetts) & $10 / 14 / 05$ & 704 \\
\hline Novartis Nutrition (Basel) & $2 / 11 / 05$ & 49.5
\end{tabular}

